\title{
Examining Teachers View on Primary Teaching Practices Based on Co-Teaching Model
}

\author{
Mehmet Turan $^{1}$, Betül Bayar ${ }^{2}$ \\ ${ }^{1}$ Faculty of Education, Firat University, Elazığ, Turkey \\ ${ }^{2}$ Institute of Educational Sciences, Firat University, Elazığ, Turkey \\ Correspondence: Mehmet Turan, Faculty of Education, Firat University, Elazı̆̆, Turkey.
}

Received: September 17, 2017

Accepted: October 15, 2017 Online Published: October 15, 2017

doi:10.11114/jets.v5i11.2708

URL: https://doi.org/10.11114/jets.v5i11.2708

\begin{abstract}
The purpose of the two-teacher primary teaching model is to find a solution, to some extent, for the crowded classes and the classes in which the inclusive students study in primary school. Furthermore, it is aimed to increase the efficiency of the lessons, better take care of the inclusive students, implement the constructivist approach as required, collect the attention of the students who lost their attentions, support students who have difficulties in their studies, ensure that students who learn slowly can learn the lessons completely and increase the quality of education by giving additional studies to the students who learn quickly. The co-teaching model that can be considered as an alternative in solution of the educational problems can be used effectively in the crowded classes and the classes in which the inclusive students study. Moreover, this study can be considered as an alternative model so that the "Teaching Practice" lessons taken by the teacher candidates studying at the education faculty can be more qualified and efficient.
\end{abstract}

The purpose of this study is to review the effectiveness of teaching practice in primary school based on co-teaching model. In this context, it was tried to determine the opinions of primary school teachers about the co-teaching model. To achieve this purpose, 12 primary teachers serving in the city center of Muş were determined as working group. In the study, the data were obtained by semi-structured interview method. Content analysis was used for the analysis of the data.

According to the teachers' opinions obtained as a result of the study, the most important one of the problems experienced by the teachers during the teaching period is the crowded classes. It is concluded that in the crowded classes, the activities are not implemented at the desired level, it is not possible to allocate enough time for the students, incorrect and incomplete learning of students cannot be realized on time and it is difficult to give a student-centered education.

As a result of the study, in order to ensure that the teaching practice can be efficient, it is concluded that the internship duration should be extended, the teacher candidates should be assigned more responsibilities, the teacher candidates should do internships in the rural schools and combined classes so that they can see different environments and they should carry out implementation-oriented studies rather than observation-oriented studies in this lesson.

According to the teachers' opinions obtained as a result of the study, it is concluded that the co-teaching model will increase the efficiency of the lesson, the classroom management will be easier, this model will ensure that the students who fall behind and learn slowly can learn the lessons completely, the saving on time will be ensured, the opportunity to take care of students personally will increase, the workload of the teachers will decrease, the equal opportunity in education will be ensured by taking care of the inclusive students more than before and the faster and more practical solutions will be created for the problems to be encountered in the teaching process.

Keywords: two-teacher model, crowded classes, teaching practice, co-teaching model

\section{Introduction}

Education is process where the elements of teacher, student, parent, and school come together and carried out. In this process, especially school and class population play an important role in terms of effectiveness and efficiency. The crowdedness of classroom population reduces the efficiency of the teaching process.

In spite of the increase in the number of schooling requests due to population increase, the efficiency of the teaching process is decreased in the crowded classrooms as a result of number of schools and classrooms not increasing 
sufficiently and in classrooms where inclusive students are found. Thus, teachers and students may encounter some problems in the teaching process. It can be said that crowded classrooms cause psychological, social and physiological problems on teachers and students.

A more restrictive teaching methods can be used in classrooms with more students. Crowded classrooms cause the time of teacher to be wasted. In these classrooms, the teacher can spend less time on each student, the process of tracking student development becomes more difficult, the classroom cannot be managed effectively and the effective learning process becomes more difficult.

It is impossible for teachers to take control as a whole in crowded classrooms. Since there is only one negative situation in crowded classrooms, it will be difficult for teachers to resist negativities in their education activities when they lose control of the classroom (Öztürk, 2003).

In crowded classrooms, namely, classrooms with more than 30 students, the effectiveness and efficiency of education activities will decrease. As a reflection of this situation in question, it is also necessary to discuss the equality of opportunity among students in education and the unity of fair practices. In this context, one of the suggested methods for solving the problem is the need for a model to have two teachers in the classrooms, which is practiced in some developed countries (Turan, 2013).

In addition, the newly appointed teachers have more difficulties in both their initial assignments and in the crowded classrooms compared to the teachers experienced in management. Therefore, this research is of great importance both in terms of good practice of the assignments based on guidance and training of newly appointed teachers and efficient carrying out of education process of the two-teacher classroom teaching where experienced teacher is working in crowded classrooms and the newly appointed teachers are acting as co-teachers for the experienced teachers.

\subsection{Purpose of the Research}

The purpose of this research is to examine opinions of teachers on teaching practice in primary school based on a two-teacher model. Answers to the following questions were sought within this scope.

1. What are the opinions of primary school teachers on the co-teaching model?

2. What are the opinions of teachers on the implementation of the co-teaching model in crowded classrooms?

3. What are the advantages and disadvantages of the co-teaching model according to the opinions of teachers?

The purpose of the two-teacher classroom teaching model identified in this research is to find a solution, to some extent, for the crowded classrooms and the classrooms where inclusive students are located. It also aims to increase the efficiency of the course, to better attend inclusive students, to implement constructivist approach properly, to focus the attention of distracted students, to support students who have difficulties in their studies, to ensure slow learners to fully learn and to increase the quality of education by providing additional studies to quick learning students.

With this research, it is aimed to examine the problems experienced in the crowded classrooms during the education process according to the opinions of the teachers and teacher candidates and to propose solutions to these problems. However, it is also aimed to develop a model that improves the quality and efficiency of "Teaching Practice" courses which are among the courses taken by teacher candidates who have studied in the education faculties in order to increase the efficiency in teaching

\subsection{The Importance of the Research}

Today, the practice of two-teacher practice is influential in the practice of putting theoretical knowledge of the students in the schools into practice and projects and group works for the acquisition of the working spirit and practice of working as a team and for obtaining positive results as a result of individual studies performed by the students.

In relation to number of classrooms where there are fewer students, teachers will be able to more easily recognize and prioritize different skills of students individually and find the possibility of attending each student personally (Yaman, 2010, p. 412).

In non-crowded classrooms, teachers can use more effective teaching techniques. However, in classrooms where the number of students is few, the teacher can control the classroom more easily. The classrooms in question have the benefits of teacher using the lesson time, getting maximum efficiency with minimum training material, allocating more time individually to the students, and keeping the development of students in a simpler way (Celep, 2002, p. 14).

It is important that this study is a model and developed in the coordination of MEB-YÖK in terms of the more qualified and efficient execution of the Teaching Practice courses taken by the candidate teachers who are studying in the Faculty of Education. Because the current teaching practice course does not allow the teacher candidates to develop themselves enough and make practice, a co-teaching model is needed. 


\subsection{Literature}

The problem with the crowded classrooms, which is the problem that the education system practiced in Turkey, is known by everyone, but is not at the forefront of the debate, seems to have been removed in countries that are at advanced level in terms of education, but the necessary measures are not taken in our country (Yaman, 2006, p. 14). The reason for the crowded classrooms (Seferoğlu, 2004, p. 47), which is of great concern in terms of the control and management of the classroom, especially in terms of the teachers who have begun their duty, is due to lack of sufficient number of schools and classrooms. This causes the quality of education to not be realized at the desired level (Ögülmüş and Özdemir, 1995, p. 29).

For quality education, it is necessary to have 11-20 students in a classroom in preschool education, 25-30 students in basic education and 20-25 students in secondary education. If the number of students in a class is higher than these figures, the cost per student is decreasing, but the quality of the education given to the students is also decreasing (Başaran, 1988, p. 94). Classrooms can be examined in three types, in terms of their size. These are; small classrooms with number of students less than 20, normal classrooms with number of students between 20 and 30, and crowded classrooms with number of students more than 30 (Işı1k, 2004, p. 56).

In the schools found in rural areas, while the number of students are very low or non-existent due to migration to cities, the students are trying to be educated in the overcrowded classrooms in cities (Türkmen and Ergün, 1997, p. 34). Despite bilateral education in these places where population increases due to internal migration, the fact that the classes are very crowded reduces the quality of education (Tezcan, 1994, p. 49).

The problems that students have experienced in relation to the crowded classrooms are collected under three headings: physical, health-cleaning and education-related. It is also emphasized that the number of students in crowded classrooms is insufficient in terms of time, that teachers are not interested in the subjects that they are interested in and talented of, that they cannot return to their problems or questions and that quality in education and training activities may be low (Bakioğlu and Polat, 2002, p. 151-154).

The school population is very important for an educational plan. The school population is important for planning how much of this population is schooled and whether the number of teachers, schools, and classrooms available is sufficient (Adem, 1981, p. 94). During the period when the compulsory education in Turkey was increased to 8 years, the "Catch Up with The Times in Education 2000 Project" aiming for contemporary levels at primary education level was implemented. Within the framework of the project, it is aimed that the level of schooling in primary education is realized at $100 \%$ level, limit the maximum number of students in classrooms to 30 and increase the quality of primary education by discontinuing the combined class practice (MEB, 2002).

The difficulty in managing crowded classrooms increases the teacher's job stress and reduces job satisfaction (Bakioğlu, 1999, p. 101; Çelik, 2002, p. 73; Çınar, 2004, p. 7). As the number of students in the class decreases, the success of the students increases (Küçükahmet, 2003, p. 50). In classrooms with a small number of students, it is possible for the teacher to use time effectively and efficiently, and the supervision and control of the teacher will be at a high level in the classroom (Celep, 2002, p. 14). In the classrooms where a few students are located, it will be easier for the students to be recognized by the teacher and show personal interest, and communication between the student and the teacher will be effective and efficient.

The purpose of the two-teacher classroom teaching model found in this research is to find a solution, to some extent, for the crowded classrooms and the classrooms where inclusive students are located. It also aims to increase the efficiency of the course, to better attend to inclusive students, to implement constructivist approach properly, to focus the attention of distracted students, to support students who have difficulties in their studies, to ensure slow learners to fully learn and to increase the quality of education by providing additional studies to quick learning students.

The advantages and disadvantages of having more than one teacher in special education classrooms, the importance of co-ordination of teachers, making the division of labor according to strengths and weaknesses and sharing the experiences of teachers are stated to contribute to the success of the students (Karasu and Mutlu, 2014, p. 55). Equipment and personal support can be provided in making physical, social and psychological arrangements and preparations necessary for the successful implementation of inclusion in general education environments. In addition, the newly appointed teachers have more difficulties in the crowded classrooms compared to the teachers experienced in management. Instead, experienced teachers can work in crowded classrooms and newly assigned teachers can work alongside the experienced teachers.

Stain (2012), expresses some topics that may be discussed by all teachers to ensure positive progress of co-teaching relationship as "Talk about our personal strengths and weaknesses", "Discuss the ways to be flexible and proactive" and "Discuss the learning environment". The essence is that every teacher in the co-teaching environment is doing his/her 
best to maintain the commitment, passion and energy necessary to maintain communication and make learning important.

There are many different co-teaching or team teaching models in schools, but one of the most common is to match a general educator with a teacher who specializes in the specific needs of the students. Although the co-teacher pair is structured differently, there are similarities among the most frequently applied teaching types in classrooms where co-teaching is practiced. Types of co-teaching are as follows (Dooley, 2014):

1. One person teaches, one person observes: This model allows members of the co-teaching team to know each other and to direct all the strength of one of the teachers to an area.

2. One person teaches, one person walks around: This model is also great for new teams. One teacher is in the role of principal narrator, while the other walks around in the classroom and interacts with students or groups.

3. Parallel teaching: In this type of teaching, students are divided into two groups, each of which is managed by one of the co-teachers. This strategy allows reviewing or special attention to a smaller student group which has trouble learning a subject.

4. Teaching with terminals: Use of terminals is not a new concept, but in a classroom with co-teaching practice, these terminals can be customized to meet the needs of students.

5. Alternance teaching: In this scenario, one of the co-teachers works in a different place with the students who need a more intensive intervention or need to review the material before moving on to the next topic. This model is effective in re-teaching or test review subjects.

6. Teaching as a team: Teaching as a team is ideal where both teachers are comfortable with content, students and each other. In a classroom where teaching is made, teachers change roles throughout the lesson without becoming dominant in the class. Lessons are mainly based on communication and interaction between teachers and students. In this research, one person teaches, one person walks around and teaching as a team co-teaching model were carried out practically. For this, the faculty of education, teaching practice course was used.

Teaching practice is a course which aims to transform the knowledge learned by teacher candidates into skill in the school setting. Teaching practice is the most important link of the process leading to teaching. The activities performed in the practice enable the teacher candidates to learn the teaching profession by living and by doing. If the selection of practicing teacher is based on volunteering rather than obligation, the efficiency obtained in the teaching practice course will also increase. This course, which is carried out in company with the faculty teaching staff and practice teacher, consists of a total of 8 hours given in the faculties, of which 6 hours are in the practice school and 2 hours are in the faculties as theoretical (YÖK, 1998, p. 61; MEB, 1998, p. 59).

Karaca and Aral (2011, p. 103), Yeşilyurt and Semerci (2011, p. 80), Ünver (2003, p. 20) and also Gökçe and Demirhan (2005, p. 63), in the researches they have conducted, reported that teachers and teacher candidates do not have sufficient knowledge of their mutual responsibilities and that there is a problem of cooperation and communication between them. In addition, because of the lack of cooperation between the school and the universities, the teacher candidates were found to have problems. Karadüz et al. (2009, p. 96), (Sahin and Kartal, 2013), Seçer et al. (2010, p. 23), Sarıtaş (2007, p. 41).

A more restrictive teaching methods can be used in classrooms with more students. Crowded classrooms cause the time of teacher to be wasted, the teacher can spend less time on each student, the process of tracking student development becomes more difficult, the classroom cannot be managed effectively and the effective learning process becomes more difficult. Teacher candidates will be able to overcome difficulties by receiving support from practice teachers when they do their internships in crowded classrooms. Thanks to this, when teacher candidates are appointed, they will not suffer these troubles.

Co-teaching is two teachers (candidate teacher and cooperating expert teacher) working with a group of students by sharing the activities of planning, organization, speaking and education as well as the physical environment (Bacharach, Heck and Dank, 2004, p. 144). In co-teaching, candidate teachers and expert teachers are encouraged to plan together and to combine co-teaching strategies with their own practices, providing opportunities for students to interact with both adults in the classroom. The expert teacher continues to interact with the classroom by applying strategies to support the learning and interaction of the students. The co-teacher duo collaborates throughout the whole experience, as the responsibility and decision-making authority switches to candidate teacher in time. Eventually, the candidate teacher assumes leadership in all aspects of the classroom, including managing the activities of the expert teacher and other adults who work with students for a predetermined period of time (University of Minnesota, 2012).

With this research, it is aimed to examine the problems experienced in the crowded classrooms during the education 
process according to the opinions of the teachers and to propose solutions to these problems. However, it is also aimed to develop a model that improves the quality and efficiency of "Teaching Practice" courses which are among the courses taken by teacher candidates who have studied in the education faculties in order to increase the efficiency in teaching.

\section{Method}

\subsection{Model of the Research}

Qualitative interview technique based on observation was used in this research. The data were obtained by semi-structured interview method from 12 classroom teachers working in two primary schools affiliated to MEB in Muş province, in 2016-2017 education year.

The research was conducted as follows: Candidate teachers participated in the course as an observing teacher for the first month on a certain day of the week for one month and as an individual participant teacher (practitioner) in the following month. Then, a semi-structured interview was then applied to the classroom teachers in order to identify their opinions on this practice.

According to Yıldırım and Şimşek (2013), "qualitative research is a research process in which qualitative data gathering methods such as observation, interview and document analysis are used and the perceptions and events are monitored in a realistic and holistic manner in the natural environment".

\subsection{Study Group}

The study group of this research consists of 12 classroom teachers working in Şehit İzzettin Polat and Fatih primary schools in Muş province, in 2016-2017 education year.

\subsection{Data Collection Tools}

The data were obtained by interviewing the teachers by the researcher. Interview questions prepared by the researcher were applied to the class teachers. As a result of the literature review, domestic and foreign studies made with the co-teaching model were examined and the interview forms of teacher and teacher candidates determined by this examination were presented to the field experts. The necessary arrangements have been made on interview questions prepared in the light of the feedbacks and suggestions of field experts and classroom teachers. The interview form consisting of a total of 12 questions was formed.

\subsection{Data Collection Process}

As data collection process in research; Firstly, in the course of teaching practice, teacher candidates carried out direct individual teaching course in the first 4 weeks and in this process classroom teacher observed the teacher candidates. In the following 4 weeks, these lessons were carried out by both the class teacher and the candidate teacher in accordance with the co-teacher model. The purpose of this is to evaluate the comparison of the current applied teaching practice lesson with the co-teacher model easier and more reliable by the teachers. At the end of the eighth week, 12 teachers were interviewed. The interview form and audio recorder were used in the interview process. The researchers participated in this process as coordinator and observer.

\subsection{Analysis of Data}

The data collected in the research were determined in the direction of the purpose of research and the analysis was made as follows. The data were obtained qualitatively. All qualitative data were analyzed by content analysis. Coding were created based on the common opinions of two researchers. The reason for taking common opinions of the two researchers is to reflect the objectivity of working with minimum subjectivity and also to be aware of the unrelated comments and categories in the data of working with different researchers. In this study, therefore, it was ensured that different researchers have been able to examine the categories in the study. A consistency of $97 \%$ was obtained in the comparison made for the analysis of the data. This finding is important for the reliability and validity of the research.

\section{Findings and Interpretations}

In this section, the findings for the codes and the themes obtained from the opinions of the classroom teachers on the co-teaching model are presented.

\subsection{Findings Related to Demographic Data of the Classroom Teachers Participating in the Research}

Gender, educational status, professional seniority of the teachers is given in Table 1 for describing the sample 
Table 1. Distribution of the demographic data of teachers participating in the research

\begin{tabular}{ccc}
\hline & Variables & $\mathrm{f}$ \\
\hline Gender & Female & 7 \\
Educational & Male & 5 \\
Status & Undergraduate & 12 \\
& Graduate & - \\
Professional & $1-5$ Years & 2 \\
Seniority & $6-10$ Years & 6 \\
& $11-5$ Years & 2 \\
\hline
\end{tabular}

When Table 1 is examined, it is seen that of the teachers who participated in the research, 7 are women and 5 are male classroom teachers. In addition, all the teachers participating in the research are undergraduates. It is also seen that the seniority of 2 of the teachers is between 1 and 5 years, 6 is between $6-10$ years, 2 is between $11-15$ years and 2 is at 16 years and over.

\subsection{Opinions of Classroom Teachers Regarding the Problems They Experience in the Teaching Process}

Table 2. Opinions of classroom teachers regarding the problems they experience in the teaching process

\begin{tabular}{lc}
\hline Opinion & $\mathrm{f}$ \\
\hline Classrooms being crowded & 6 \\
Readiness levels of students being different & 5 \\
Classroom management & 5 \\
Not being able to activate the students & 5 \\
Not being able to give students sufficient voice & 5 \\
Not being able to attend to students personally & 4 \\
Lack of materials & 3 \\
Lack of time & 2 \\
\hline
\end{tabular}

When the data in Table 2 are examined, it is seen that the opinions of the participating classroom teachers about the problems they experienced during the teaching process are collected under 8 different codes. The most emphasized of these codes is the crowdedness of the classrooms, the difference in the level of readiness of the students, the classroom management and not being able to give students sufficient voice. Below, examples from the answers of the teachers on this situation are presented.

The crowdedness of my classroom population is the main problem I am experiencing $(T, 9)$.

Although I am experienced, I cannot be very productive when I am lecturing in crowded classrooms $(T, 11)$.

The hardest part of the teaching profession is managing a crowded classroom $(T, 12)$.

I wanted to provide students with a more effective and lasting education by activating them using different methods and techniques (T,7).

\subsection{Opinions of Teachers Regarding the Need for a Co-Teacher}

Table 3. Opinions of teachers regarding the need for a co-teacher

\begin{tabular}{ll}
\hline Opinion & $\mathrm{f}$ \\
\hline Yes & 10 \\
No & 2 \\
\hline
\end{tabular}

When the teachers need for co-teacher is examined, the result was 10 teachers needed and 2 teachers did not need.

Although I do not need a co-teacher, when we think in general, I think there may be a need for a co-teacher in crowded or combined classroom schools. $(T, 1)$.

I think it will be useful especially for students who are behind the class level (T,3).

I do not need a co-teacher. Since students are accustomed to the teaching style of their teachers, they will have difficulty with a new teacher $(T, 4)$.

A co-teacher would be very helpful in solving our problems (T,7). 


\subsection{Opinions of Classroom Teachers Regarding the Subjects Teacher Candidates Exchange Opinions About}

Table 4. Opinions of classroom teachers regarding the subjects teacher candidates exchange opinions about

\begin{tabular}{ll}
\hline Opinion & $\mathrm{f}$ \\
\hline Teaching method technique & 6 \\
Class level & 3 \\
Time management & 2 \\
Material & 3 \\
Focusing attention & 2 \\
The contents of next lesson & 2 \\
\hline
\end{tabular}

When the data in Table 4 are examined, the teaching methods and techniques are the main subjects teacher candidates exchange opinions with teachers. This finding can be interpreted as the teacher candidates experiencing difficulties in choosing teaching methods and techniques.

Teacher candidate asked for my opinions before the subject, regarding what kind of a method to follow for focusing attention of the students. Apart from this, opinions were exchanged about teaching method techniques and preparation of material related to the lesson $(T, 1)$.

In particular, opinions were exchanged regarding getting level with the student, preparation process, presentation style, level of achievement and class guidance $(T, 10)$.

I suggested that a visual presentation of a subject that can be expressed using pages of verbal expressions can be explained in a shorter time and more permanently $(T, 4)$.

3.5 Opinions of Teachers Regarding Evaluation of Candidate Teachers in terms of Being Role Models

Table 5. Opinions of teachers regarding evaluation of candidate teachers in terms of being role models

\begin{tabular}{ll}
\hline Opinion & $\mathrm{f}$ \\
\hline I think it is sufficient & 8 \\
I think it is partially sufficient & 4 \\
I think it is not sufficient & 0 \\
\hline
\end{tabular}

According to Table 5, the majority of the participating classroom teachers find themselves sufficient in terms of being role models for the candidate teachers. 4 of the teachers found themselves partially sufficient while no teachers found themselves sufficient.

I believe that I am an example to candidate teachers with my approach to students, desire to create an enjoyable learning environment, being open to innovation and suggestions, study lessons with different teaching techniques $(T, 1)$.

Although I am sufficient in theoretical knowledge in terms of university education, the classroom environment is quite different. The real trick is to transfer this to the classroom environment. I try to develop myself by discovering new things every passing day. I try to be beneficial to candidate teachers as far as I can $(T, 9)$.

3.6 Opinions of the Classroom Teachers Regarding the Practice of Co-Teaching Model

Table 6. Opinions Regarding the Practice of Co-Teaching Model

Opinion

I think it is necessary.

Especially in crowded classrooms.

It may be useful for students who are behind the classroom level.

It may cause waste of time.

According to the data on Table 6, 11 of the participating teachers see the co-teaching model as necessary. Example statements:

I think it would be absolutely beneficial. But this model maybe before the school is over 4th grade maybe completely converted into this model and candidate teachers should participate in this process. I don't think anyone would not want to work as a second teacher after school is over and they are assigned (T,3).

I find it necessary because turning disadvantaged situations of the crowded classes into advantages is not only a way to relieve teachers physically but also psychologically $(T, 6)$.

With this model, more time will be spared for students who are left behind in crowded classes (T,11).

It is necessary for students behind the class level $(T, 12)$. 
3.7 Opinions of the Classroom Teachers Regarding the Advantage of Co-Teaching Model

Table 7. Opinions of the classroom teachers regarding the advantage of co-teaching model

\begin{tabular}{ll}
\hline Opinion & $\mathrm{f}$ \\
\hline Increases the efficiency of the lesson. & 6 \\
Allows attending to students personally. & 6 \\
Brings the slow learning student classroom level. & 5 \\
Decreases the workload of the teacher. & 4 \\
More time is spared to the inclusive student. & 3 \\
Makes the teacher more productive. & 3 \\
Prevents waste of time. & 2 \\
In-class activities are performed easier. & 2 \\
Classroom management becomes easier. & 2 \\
Reduces distraction. & 1
\end{tabular}

When the data in Table 7 were examined, it was seen that opinions of the participating classroom teachers regarding the advantages of the co-teacher model were collected under 11 codes. Among these codes, the most emphasized ones are 6 increases efficiency of the lesson, 6 allows attending to students personally, and 5 brings the slow learners to the classroom level. This finding suggests that there is a need for co-teacher model to increase the efficiency of the lesson.

Increasing the efficiency of the course, better attending to inclusive students, focusing the attention of distracted students, and ensuring slow learning students to fully learn are some of the advantages of this model (T,1).

The main advantage of this model is increasing the education quality of children by increasing the efficiency of lessons $(T, 7)$.

It provides opportunities for more and effective attending to each child in classrooms where population is high and with inclusive students (T,7).

Allows preparing a program suitable for the student by taking into account the individual differences $(T, 10)$.

It is beneficial in terms of attending to the students left behind $(T, 2)$.

It provides an opportunity to complete the shortcomings of the students left behind in level and enables them to reach the level of other students $(T, 3)$.

Decreases the documentation burden of the teacher $(T, 4)$.

More time can be spared to inclusive student and their shortcomings may be completed more (T,9).

A teacher can work more efficiently without working too much (T,3).

3.8 Opinions of the Classroom Teachers Regarding the Limitations of Co-Teaching Model

Table 8. Opinions teachers regarding the limitations of co-teaching model

\begin{tabular}{ll}
\hline Opinion & $\mathrm{f}$ \\
\hline A problem of harmony between teachers is experienced. & 9 \\
A problem of authority is experienced. & 5 \\
Causes groupings among the students. & 3 \\
Distracts the students. & 3 \\
It is not economical. & 3 \\
Difficulty in task sharing is experienced. & 3 \\
Students experience difficulty as to which one to take as a role model. & 1 \\
The need for planning and preparation increases. & 1 \\
Additional classrooms and time are needed. & 1
\end{tabular}

When the data in Table 8 were examined, it was seen that opinions of the participating classroom teachers regarding the limitations of the co-teacher model were collected under 9 codes. Among these codes, the most emphasized ones are 9 
problem of harmony between teachers is experienced, 5 thinks problem of authority is experienced.

If the harmony and coherence between the teachers is not good, the activities may not be efficient $(T, 1)$.

The biggest problem in this model is to ensure job division and harmony $(T, 6)$.

There may be difference of opinion between the teachers $(T, 11)$.

Teacher's authority can be shaken $(T, 12)$.

May cause groupings among the students $(T, 1)$.

I think it can divide the attention into two $(T, 2)$.

I think it may cause difficulties economically $(T, 10)$.

The biggest problem in this model is to ensure job division and coordination (T,6).

There is too much need for planning and preparation $(T, 12)$.

3.9 Opinions of the Classroom Teachers Regarding the Contribution of Co-Teacher Model into Classroom

Table 9. Opinions regarding the contribution of co-teacher model into classroom management and teaching process

\begin{tabular}{lc}
\hline Opinion & $\mathrm{f}$ \\
\hline Ensures effective participation of the student. & 5 \\
Brings the students left behind to classroom level. & 4 \\
Makes classroom management easier. & 4 \\
Increases success. & 1 \\
Saves time. & 1 \\
\hline
\end{tabular}

When Table 9 is examined, opinions regarding the contribution of co-teacher model into classroom management and teaching process are collected under 5 codes. The most emphasized are, 5 ensures effective participation of the student, 4 brings the students left behind to classroom level, 4 makes classroom management easier.

With this method, classroom management will be more convenient and participation in the teaching process will be faster and more effective $(T, 1)$.

It is useful for attending personally to the students who are left behind $(T, 4)$.

I think it will have an effect of making classroom management easier (T,9).

It will increase the success because it will save time and make classroom management easier (T,12).

3.10 Opinions of the Classroom Teachers Regarding the Applicability of Co-Teaching Model in Crowded Classrooms

Table 10. Opinions regarding the applicability of co-teaching model in crowded classrooms

\begin{tabular}{ll}
\hline Opinion & $\mathrm{f}$ \\
\hline The opportunity to attend to students personally increases. & 6 \\
The quality of education and teaching increases. & 3 \\
Facilitates classroom management. & 3 \\
Decreases the workload of the teacher. & 3 \\
Allows making additional work. & 2 \\
Ensures development of different dimensions of intelligence. & 1 \\
\hline
\end{tabular}

When Table 10 is examined, opinions about the applicability of the co-teacher model in crowded classrooms are collected under 7 codes. The most emphasized of these codes is the opportunity to attend to students personally increases.

The opportunity to attend to students personally or as groups increases $(T, 1)$.

Provides opportunity to attend to students who are left behind personally $(T, 4)$.

Thanks to co-teaching model, the opportunity of making additional work for students increases $(T, 1)$. 
3.11 Opinions of the Classroom Teachers Regarding the Applicability of Co-Teaching Model in Classrooms with Inclusive Students

Table 11. Opinions of the classroom teachers regarding the applicability of co-teaching model in classrooms with inclusive students

\begin{tabular}{ll}
\hline Opinion & $\mathrm{f}$ \\
\hline Allows attending to student personally. & 10 \\
Saves time for teacher. & 4 \\
Provides equality of opportunity. & 2 \\
Makes the student feel valuable. & 1 \\
\hline
\end{tabular}

When Table 11 is examined, findings regarding the applicability of co-teaching model in classrooms with inclusive students are collected under 4 codes. The most emphasized of these codes 10 of them the opportunity to attend to students personally increases.

While the first teacher attends to inclusive student (without distracting other students). The second teacher may attend to other students $(T, 1)$.

While one is attending to inclusive student, the other teacher teaches a lesson $(T, 11)$.

Since the student will be attended to personally, the student can be made to feel special and the student becomes more diligent $(T, 9)$.

3.12 Opinions of the Class Teachers regarding the Employment of a Second Teacher by MEB in the Crowded and Inclusive Student Containing Classrooms

Table 12. Opinions of the class teachers regarding the employment of a second teacher by MEB in the crowded and inclusive student containing classrooms

\begin{tabular}{ll}
\hline Opinion & $\mathrm{f}$ \\
\hline Would be useful. & 8 \\
Currently impossible for our country. & 2 \\
Should be implemented by providing the necessary infrastructure. & 2 \\
Should be applied in the required classrooms considering the number of classrooms. & 1
\end{tabular}

When Table 12 is examined, it is seen that 8 teachers are of the opinion that the employment of a second teacher by MEB in the crowded and inclusive students containing classrooms would be useful.

I think it is a great necessity that will make the job of the teacher easier, increase the individual interest of the classroom, and create environments where the students will be more active $(T, 8)$.

Although I argue that it will be difficult to implement in public schools, it will of course be contributing. A model that should be applied as it facilitates the activation of students $(T, 9)$.

Although I think that employing a second teacher in a classroom would be beneficial to crowded and inclusive student containing classrooms, it seems impossible for such a situation to happen when the economic and social conditions of our country are taken into consideration $(T, 1)$. 


\subsection{Opinions of Classroom Teachers Regarding Comparison of Single Teacher and Co-Teacher Models}

Table 13. Opinions of classroom teachers regarding comparison of single teacher and co-teacher models

\begin{tabular}{|c|c|c|}
\hline Opinion & & $\mathrm{f}$ \\
\hline Single Teacher Model & Co-Teacher Model & \\
\hline $\begin{array}{l}\text { Workload and responsibilities of the } \\
\text { teacher is high. }\end{array}$ & $\begin{array}{l}\text { Workload of the teacher is low, } \\
\text { responsibility is shared. }\end{array}$ & 4 \\
\hline $\begin{array}{l}\text { It is difficult to include all students in the } \\
\text { teaching process. }\end{array}$ & $\begin{array}{l}\text { All students in the classroom are easily } \\
\text { accessible. }\end{array}$ & 4 \\
\hline Classroom management is difficult. & Classroom management becomes easier. & 4 \\
\hline $\begin{array}{l}\text { Personal or group teaching planning is } \\
\text { difficult. }\end{array}$ & $\begin{array}{l}\text { Used effectively in personal or group } \\
\text { teaching. }\end{array}$ & 2 \\
\hline $\begin{array}{l}\text { It is difficult to use different teaching } \\
\text { methods and techniques. }\end{array}$ & $\begin{array}{l}\text { Different teaching methods and } \\
\text { techniques can be used. }\end{array}$ & 2 \\
\hline It's more economical. & It is not economical. & 1 \\
\hline $\begin{array}{l}\text { It causes waste of time in the crowded and } \\
\text { inclusive student containing classrooms } \\
\text { and full learning cannot be achieved. }\end{array}$ & $\begin{array}{l}\text { It decreases waste of time in the crowded } \\
\text { and inclusive student containing } \\
\text { classrooms and full learning can be } \\
\text { achieved. }\end{array}$ & 1 \\
\hline Individual differences may be overlooked. & Individual differences are emphasized. & 1 \\
\hline Time management is difficult. & Time management is easier. & 1 \\
\hline $\begin{array}{l}\text { There is a monotone learning } \\
\text { environment. }\end{array}$ & $\begin{array}{l}\text { It creates an effective and fun learning } \\
\text { environment. }\end{array}$ & 1 \\
\hline $\begin{array}{l}\text { It is difficult to ensure equality of } \\
\text { opportunity. }\end{array}$ & Equality of opportunity is ensured. & 1 \\
\hline
\end{tabular}

When Table 13 is examined, it can be seen that 4 of the teachers were of the opinion that workload in single teacher model is high and workload in co-teaching model is low, the responsibility is shard; 4 that it is difficult to include all students to teaching process in single teacher model while easy in co-teaching model, 4 that classroom management is difficult in single teacher model while it may be easier in co-teaching model.

\subsection{Opinions of Classroom Teachers Regarding the Teaching Practice Lesson Being More Effective}

Table 14. Opinions regarding the teaching practice lesson being more effective

\begin{tabular}{ll}
\hline Opinion & $\mathrm{f}$ \\
\hline The internship period should not be limited to one day a week. & 5 \\
Teacher candidates should be in more contact with teachers. & 5 \\
Teacher candidates should be given more responsibility. & 4 \\
A comfortable environment in which teacher candidates can express themselves should be created. & 2 \\
Internships should be made in classrooms of different types. & 2 \\
Internship should also be done in village schools. & 2 \\
\hline
\end{tabular}

In Table 14, when the opinions obtained on the teaching practice lesson being more effective are examined, it is seen that 5 of the teachers are of the opinion that internship period not being limited to one day of the week, 5 are that the teachers and teacher candidates are more in communication and 4 are that teacher candidates should be given more responsibility.

I think it would be more beneficial to do internship for one year instead of one day a week. I think that all of the fourth grade should be for (T, 2).

Teacher candidates should be in greater communication and collaboration with classroom teachers $(T, 5)$.

The teacher candidate must engage in a rigorous dialogue with the practice teacher and pay attention to the points indicated by them $(T, 8)$.

In the context of teaching practice activities, the works they do should be increased. At the same time, the responsibilities in lecturing and classroom management should be increased $(T, 10)$.

Teacher candidates should be provided an environment where they can prove and express themselves comfortably $(T, 10)$. 
In different types of classes (crowded-less students, older age group-younger age group, normal class-unified class, etc.). Internship opportunities should be provided $(T, 1)$.

\section{Discussion}

The research was conducted on 12 classroom teachers in Muş province of Turkey. Of the teachers participating in the research, 7 are females and 5 are males. The research was carried out in Muş city center. All teachers are undergraduates. According to professional seniority variable, 2 of the participants have 1-5 years, 6 have 6-10 years, 2 have 11-15 years and 2 have 16 years and more professional seniority.

The main finding regarding the problems experienced by the teachers in teaching process is the classrooms being crowded. Sarıer (2010), in his study, has reported that crowded classrooms is the main problem decreasing the quality in education, that the given program cannot be implemented fully and that the expected targets cannot be achieved because the teacher-student interaction is not sufficiently ensured in the crowded classrooms and that the crowded classrooms is one of the problems creating quality crisis and required urgent solution. This result is supported by findings obtained in the studies of Yapıc1 and Demirdelen (2007) and Bal (2008). It also overlaps with the study of Korkmaz (2006). As an obstacle to the solution of many problems, from teaching method and technique selection to measurement evaluation, crowded classes can be considered as an important factor that will affect student success. Since the constructivist approach is student-centered, students need to take an active role in their learning. However, in crowded classrooms, there are difficulties in applying the activities as desired, not sparing sufficient time for the students, and inability of detecting shortcomings of the student are experienced. Practicing co-teaching model as a solution to the problem of crowded classes can affect student achievement positively.

Teachers express what they need a co-teacher for the students left behind in learning, for the students with attention deficit and for those who are inclusive students.

It was concluded that teacher candidates exchanged information with practice teachers regarding teaching method technique, class level, time management, material, focusing attention, what to do in the next lesson. The vast majority of the teachers stated that teacher candidates obtained information about the teaching methods and techniques. In this case, teacher candidates show themselves to be inadequate in method and technique. This result is supported by findings obtained in the studies of Kösterelioğlu and Kösterelioğlu (2008).

It has been identified that the teachers find themselves sufficient in terms of being role models for the teacher candidates. This result is supported by findings obtained in the study of Sarıçoban (2008). Candidate teachers participating in school experience and practice courses should be given adequate guidance by their practice teachers to contribute to their professional development. In their study, Gökçe and Demirhan (2005) reached to the conclusion that most of the practice teachers have fulfilled the expectations in most of the activities within scope of the teaching practice lesson.

It was concluded that the vast majority of teachers have found co-teacher model necessary. This is an important finding. MEB can apply this model in crowded classrooms and in classrooms containing inclusive students. Genç and Eryaman (2008) stated in their study that equality of opportunity in education means giving opportunity to individuals to develop their skills and intelligence at the optimum level by gaining meaning beyond providing education to the poor, and for this reason education institutions can provide equality of opportunity in the way that individuals can realize and develop their interests and abilities. Y1lmaz and Altınkurt (2011) point out that one of the most fundamental problems of the Turkish education system is that the inequality of opportunity in education increases day by day and this increase deepens the social stratification. With the implementation of the co-teacher model, it will be more convenient to increase both the quality and equality of opportunity in education.

When the findings on the advantages of the co-teacher model were examined, half of the teachers indicated that it would increase the efficiency of the lesson, while half of them indicated that the possibility attending to students personally would increase. It was also identified that the co-teacher model will bring the problem of harmony and authority problems between the teachers. One of the limitations of the co-teacher model is that more planning and preparation for the next day's class is required and less time for teachers to work together.

The result of co-teaching model ensuring active participation of the student into teaching process, brought the students who were left behind to class level and make classroom management easier was reached. With co-teacher model, students were given more importance, teachers can work with a colleague and all pressure does not fall onto one person. Although teachers seem like shy away from getting together for now, when the co-teacher model is clarified by school administrations by teachers, teachers will find this teaching style more useful for everyone. Especially when a special education teacher and a general education teacher are brought together a surprising progress can be seen.

According to Aydın (2013), teacher, student, school program, educational environment, educational management, family and environment are variables of classroom management. The most definitive of these variables is teaching. Therefore, the 
teacher is responsible in the organization and carrying out of education and training process. Therefore, in order to create a successful educational environment, teachers are tasked with integrating and harmonizing the system variables. It is also the teacher's most important task to use the methods and techniques to reveal and improve hidden powers of the students. However, in addition to the curriculum that the teacher needs to meet, the performance and time to perform them are also insufficient. However, these goals can be reached more efficiently by applying co-teaching model.

When the co-teaching model is applied in crowded classrooms, it is identified that the opportunity of attending personally to the students will increase. The co-teacher model provides more intensive and personalized education in the general education environment. Korkmaz (2006) pointed out in the study he made that administrators should provide support teachers in activity preparation because the classes are too crowded and the teachers have to fill a lot of documents, and because of their time and economic troubles.

In the classrooms containing inclusive students, when the co-teaching model is applied, it is identified that opportunities for equality of opportunity can be provided while the chance of attending to students personally increases. Demir and Acar (2010) pointed out in the study they made that the most important aim of the inclusive education, along with having more than one aim, is not to normalize the children with special needs but to recognize their hidden powers and reveal, develop and make them use these and facilitate their lives in the society. However, most of the classroom teachers, regarding the inclusive students, cannot attend to them sufficiently because they cannot find sufficient time to attend to them. Both controlling the classroom and attending with the inclusive student reduce the performance of teachers and teachers show a negative attitude towards the inclusion education. However, with the co-teacher model, the inclusive students will be sufficiently attended to and equal opportunities will be provided in education. It was concluded that employment of a second teacher by MEB in the crowded and inclusive students containing classrooms are desired by the great majority of classroom teachers.

In the single teacher model, the workload and responsibilities of the teacher are high while in the co-teacher model the workload is low and the responsibility is shared. In the single-teacher model, it is difficult including all the students into the teaching process while in co-teacher model, all the students in the class can accessible. While classroom management is difficult in the single teacher model, it is easier with co-teacher model.

Teachers stated that the internship period should not be limited to one day a week so that the teaching practice course is more efficient. This result indicated that the teacher candidates who participated in the research conducted by Baştürk (2009) also found the lesson time insufficient. It overlaps with the findings obtained from the studies Kavas and Bugay (2009). In addition, Ören, Sevinç and Erdoğmuş (2009) reported that teacher candidates gave opinions that the number of hours of this course should be increased and should not be limited to one day a week. Supported by findings from the studies of Becit, Kurt and Kabakçı (2009).

In order for the internship to be fruitful, it has been determined that the teacher candidates should be more in communication with the teachers. This result is supported by the findings obtained from the studies of Seçer, Çeliköz and Kayll (2010).

It was concluded that in order for the internship to be fruitful, teacher candidates should be given more responsibility. This result is supported by findings obtained from Özgür, Bukova, Güzel, Kula, Uğurel (2009) studies. Also, Kocadere and Aşkar (2013) stated in their studies that one of the problems arising in the teacher training system is not giving sufficient authority to the teacher candidate.

It was concluded that the practice of internship in village schools would increase in the efficiency obtained from the teaching practice course. It was revealed that teachers want teacher candidates to practice internship in village within the scope of teaching practice activities, have more experience in teaching practice and practice in more than one practice class. Turgut, Yilmaz and Füruzan (2008) suggest in the study they conducted that the teacher candidates should also practice internship in the village schools in order to see the different atmospheres. Also, supported by the findings of studies of Göktaş and Şad (2014); Nayır and Çınkır (2015).

In the two-teacher model, it is also important that the candidate teacher has the opportunity to teach alone. In addition, the newly appointed teachers have more difficulties in both their initial assignments and in the crowded classrooms compared to the teachers experienced in management. Therefore, this research is of great importance both in terms of good practice of the assignments based on guidance and training of newly appointed teachers and efficient carrying out of education process of the two-teacher classroom teaching where experienced teacher is working in crowded classrooms and the newly appointed teachers are acting as co-teachers for the experienced teachers.

It can also be considered as a model that improves the quality and efficiency of "Teaching Practice" courses which are among the courses taken by teacher candidates who have studied in the education faculties in order to increase the efficiency in teaching. 
Co-teacher model can be applied to reduce the problems with the crowded classes where the teachers experience the most difficulties during the teaching process. In addition to being implemented in crowded classrooms, co-teacher model can also be applied in the classrooms where students are distracted, have learning problems and contain inclusive students.

The authority and responsibilities of each teacher should be determined before applying the co-teacher model in order to minimize the problems that may be experienced between the teachers.

This research was conducted only on the opinions of the teachers. Research can be conducted on the opinions of teacher candidates, school administrators, education inspectors and students.

Experimental research can be done on co-teaching model.

Research on types of co-teaching and classroom designs can be done.

\section{Acknowledgments}

This study was prepared by utilizing the master thesis made in Frrat University Institute of Education Sciences Department of Primary Education Classroom Teaching Department.

\section{References}

Adem, M. (1981). Educational Planning, Ankara University Educational Faculty Education Research Center Publication No: 1, Sevinç Matbaası, Ankara

Aydin, A. (2013). Classroom Management (16th Printing), Ankara, Anı Yayıncılık.

Bakioğlu, A. (1999). The Effect of the Number of Students on School Management and School Quality. M.U Atatürk Education Faculty Journal of Educational Sciences, 11, 23-38.

Bakioğlu, A., \& Polat, N. (2002). The Effects of Crowd Classes A Preliminary Study. Education Research, 7, 147-156.

Bal, A. P. (2008). Evaluation of the New Elementary Mathematics Teaching Program in terms of Teacher Opinions. Çukurova University Journal of Social Sciences Institute, 17(1), 53-68.

Başaran, İ. E. (1988). Education Management, (2. Printing). Ankara, Kadığlu Matbaası.

Baştürk, S. (2009). Examination of Teaching Practice Course According to Opinions of Teacher Candidates. Elementary Education Online, 8(2), 439-456.

Becit, G., Kurt, A. A., \& Kabakçı, I. (2009). Opinions of Computer Teacher Candidates Regarding the Benefits of School Practice Courses, Anadolu University Journal of Social Sciences, 9 (1), 169-184.

Celep, C. (2002). Classroom Management and Discipline. Ankara, Anı Yayınc1lık.

Çelik, V. (2002). Classroom Management. Ankara: Anı yayıncılık.

Çınar, O., Temel, A., Beden, N., \& Göçgen, S. (2014, July). The Impact of Crowded Classes on Teacher and Student. XIII. National Education Sciences Congress, Malatya.

Demir, M. K., \& Açar, S. (2010). Thoughts of Classroom Teachers on Inclusive Education. Gazi University Gazi Education Faculty Journal, 30 (3), 749-770.

Dooley, S. (2014). True Teamwork: Cohesive Co-Teaching https://www.amle.org/BrowsebyTopic/WhatsNew/WNDet/TabId/270/ArtMID/888/ArticleID/460/True-TeamworkCohesive-Co-Teaching.aspx accessed on 15th April 2017).

Genç, S. Z., \& Eryaman, M. Y. (2008). Changing Values and New Education Paradigm. Journal of Social Sciences, 9(1), 89-102.

Gökçe, E., \& Demirhan, C. (2005). Opinions of the Teacher Candidates and Practice Teachers Working in Elementary Schools on the Teaching Practice Activities, Ankara University Journal of Educational Sciences, 38(1), 43-71.

Göktaş, Ö., \& Şad, S. N. (2014). Assigning the Practice Teachers for School Experience and Teaching Practice Courses: Criteria, Challenges and Suggestions. Hacettepe University Journal of Education, 29(4), 115-128.

Işık, H. (2004). Physical Layout of Learning Environments, M. Şişman and S. Turan (Editors). Classroom Management, (2nd Edition), Ankara, Pegem A Yayıncilık.

Karaca, N. H., \& Aral, N. (2011). Problems Encountered by Pre-school Teacher Candidates in Teaching Practice Problems. 2nd International Conference on New Trends in Education and Their Implications 27-29 April, 2011 Antalya-Turkey, Siyasal Kitabevi, Ankara, Turkey.

Karadüz, A., Eser, Y., Şahin, C., \& İlbay, A. B. (2009). The Effectiveness of Teaching Practice Module in Opinions of 
Final-Year Student Teachers. Mustafa Kemal University Journal of Social Sciences Institute, 6(11), 442-455.

Karasu, T., \& Mutlu, Y. (2014). Problems in Special Education from the Perspective of Teachers and Suggested Solutions: Mus Province Example. Anemon Muş Alparslan University Social Sciences Journal, 2(1).

Kavas, A. B., \& Bugay, A. (2009). Shortcomings Seen by Teacher Candidates in Pre-Service Training and Suggested Solutions. Pamukkale University Journal of Education, 25(25), 13-21.

Kocadere, S. A., \& Aşkar, P. (2013). An Examination of the Opinions on School Practice Courses and an Application Model Suggestion. Hacettepe University Journal of Education, 28(2), 27-43.

Korkmaz, İ. (2006). Evaluation of New Elementary Education First Grade Program by Teachers. Selçuk University Journal of Social Sciences Institute, 16, 419-431.

Kösterelioğlu, İ., \& Kösterelioğlu, M. A. (2008). Perceptions of Trainee Teachers about Levels of Acquiring Professional Competences. Sakarya University Science Literature Magazine, 2, 257-275.

Küçükahmet, L. (2003). Classroom Management, Ankara, Nobel Yayıncılık.

MEB, (2002). National Education Statistics 2001-2002, Devlet Kitapları Müdürlüğü Basımevi, Ankara.

Ministry of Education. (1998). Guideline on Teaching Practice to be Performed by the Teacher Candidates in the Educational Institutions Affiliated to the Ministry of National Education, Journal of the Communiqués, 2493, Ankara: Yazar.

Minnesota University (2012). What is co-teaching (http://www.cehd.umn.edu/teaching/co-teaching/foundations/what/ ; accessed on 15th April 2017.)

Nayır, F., \& Çınkır, Ş. (2015). Problems encountered by Practice Teachers, Managers and Pedagogical Formation Students in Teaching Practice in Schools and Solution Suggestions. International Journal of Curriculum and Instructional Studies, 4(7).

Öğ̈̈lmüş, S., \& Özdemir, S. (1995). Effect of class and school size on students, Education Management in Theory and Practice, 2(1), 261-271.

Ören, F. Ş., Sevinç, Ö. S., \& Erdoğmuş, E. (2009). Evaluation of Attitudes and Opinions of Teacher Candidates Towards School Experience Courses. Journal of Theory and Practice in Education Management, 15, 217-246.

Özgür, Z., Bukova, G. E., Kula, S., \& Uğurel, I. (2009). Picture of the Processes for the Professional Pre-Application Experiences in High Schools Through the Eyes of Mathematics Teacher Candidates. Inönü University Journal of Education, 10(3), 227-252.

Öztürk, B. (2003). Preventing and Eliminating Unwanted Behaviors in Classes, Classroom Management (Ed.). E. Karip, Ankara, Pegem Yayınları, 132.

Şahin, Ç., \& Kartal, O. Y. (2013). Opinions of Classroom Teacher Candidates on the Classroom Teacher Training Program. Uşak University Journal of Social Sciences, 6(1), 164-190.

Sarıçoban, A. (2008). Opinions of Practice Teachers and Teacher Candidates on School Experience and Teaching Practice Courses. Gazi University Gazi Education Faculty Journal, 28(3), 31-55.

Sar1er, Y. (2010). Evaluation of Equality of Opportunity in Secondary Education Examinations (OKS-SBS) and PISA Results. Journal of Kirsehir Education Faculty, 11(3), 107-129.

Sarıtaş, M. (2007). Evaluation of Opinions on the Benefits of School Experience I Application to Candidate Teachers. Uludă̆ University Education Faculty Journal, 20(1), 121-143.

Seçer, Z., Çeliköz, N., \& Kayılı, A. G. G. (2010). Problems Experienced in Pre-School Teacher School Practices Solution Suggestions. Yüzüncü Y1l University Journal of Education Faculty, 7(1), 128-152.

Seferoğlu, S. S. (2004). Self-evaluations of teacher candidates in terms of teacher competencies Hacettepe University Journal of Education, 26, 131-140.

Stein, E. (2012). 4 Critical Co-Teacher Conversations (https://www.middleweb.com/3905/4-critical-co-teacher-conversations/; accessed on 10th April 2017).

Tezcan, M. (1994). Immigration and Education Problems in Our Country. Ankara University Faculty of Education Journal, 27 (1), 61-67.

Turan, M. (2013). Interview with chairman of SÖDER on Classroom Teachers (https://www.ogrenmen.com/egitim-ogretim/soder-baskani-ile-sinif-ogretmenleri-uzerine-roportaj.html; accessed on April 12, 2017). 
Turgut, M., Yılmaz, S., \& Firuzan, A. R. (2008). A Study on the Evaluation of School Experience Implementation Process. University and Society, 8 (2).

Turkmen, B., \& Ergün, M. (1997). Education Planning in Turkey and Problems. Kastamonu Education Journal. 3 (4).

Ünver, G. (2003). Cooperation in Teaching Practice A Case Study. Gazi University Gazi Education Faculty Journal, 23(1), 87-100.

Washut, H. T., \& Bacharach, N. (2010). Mentoring Teacher Candidates Through Co-Teaching. Teacher Quality Enhancement Center. St. Cloud, Minnesota.

Yaman, E. (2006). A Dimension of the Problems in the Education System: Large Classes and Classroom Management. Turkish Journal of Educational Sciences, 4(3), 261-274.

Yaman, E. (2010). The Effects of Crowded Classes: What Do The Students Think. Kastamonu Education Journal, 18(2), 403-414.

Yapıc1, M., \& Demirdelen, C. (2007). Teacher Opinions on the 4th Grade Social Studies Curriculum in Elementary School. Elementary Education Online, 6(2), 204-212.

Yeşilyurt, E., \& Semerci, Ç. (2011). Problems encountered by Practice Teachers in Teaching Practice Process and Solution Suggestions. Akademik Bakıs Magazine, 27, 1-23.

Yıldırım, A., \& Şimşek, H. (2013). Qualitative Research Methods in Social Sciences (9th Edition), Ankara, Seçkin Yayıncilik

Yılmaz, K., \& Altınkurt, Y. (2011). Opinions of Teacher Candidates on the Problems of Turkish Education System. International Journal of Human Sciences, 8(1), 942-973.

YÖK, Faculty-School Cooperation (1998). Teacher Training Series, YÖK / World Bank National Education Development Project Pre-Service Teacher Training, Teacher Training Series, Ankara.

\section{Copyrights}

Copyright for this article is retained by the author(s), with first publication rights granted to the journal.

This is an open-access article distributed under the terms and conditions of the Creative Commons Attribution license which permits unrestricted use, distribution, and reproduction in any medium, provided the original work is properly cited. 